International Journal on Information Sciences and Computing, Vol.2, No.1, July 2008

\title{
CONSUMER BEHAVIOR TOWARDS MOBILE PHONE SERVICES (A COMPARATIVE STUDY BETWEEN URBAN AND SEMI URBAN MOBILE PHONE USERS IN TAMILNADU)
}

\author{
Muthumani S. ${ }^{1}$ and Thangavel $\mathbf{N}{ }^{2}$ \\ ${ }^{1}$ Research Scholar, Sathyabama Unversity, Jeppiaar Nagar, Rajiv Gandhi Road, Chennai, India \\ 2Jeppiaar Engineering College, Rajiv Gandhi Road, Chennai, India \\ E-mail : '1mcsmba@yahoo.com
}

\begin{abstract}
In fewer than twenty years, mobile phones have gone from being rare and expensive pieces of equipment used by businesses to a pervasive low-cost personal item. In many countries, mobile phones now outnumber land-line telephones, with most adults and many children now owning mobile phones The mobile phone itself has also become a totemic and fashion object, with users decorating, customizing, and accessorizing their mobile phones to reflect their personality. This has emerged as its own industry. The researcher feels that the present study helps to know the perceptions of the customers and the service providers between the two major segments. i.e. rural and urban. It gives a proper idea on the customer's expectations which in turn helps in designing the various business plans to suit the customers in different segments
\end{abstract}

Key words: Customers Perception, Comparative Study, Economic Factors, Service Factors.

\section{INTRODUCTION}

In fewer than twenty years, mobile phones have gone from being rare and expensive pieces of equipment used by businesses to a pervasive low-cost personal item. In many countries, mobile phones now outnumber land-line telephones, with most adults and many children now owning mobile phones Hong Kong has the highest mobile phone penetration rate in the world, at $125.1 \%$ in April 2006. It is not uncommon for young adults to simply own a mobile phone instead of a land-line for their residence .In some developing countries, where there is little existing fixed-line infrastructure, the mobile phone has become widespread. The mobile phone itself has also become a totemic and fashion object, with users decorating, customizing, and accessorizing their mobile phones to reflect their personality. This has emerged as its own industry. The sale of commercial ringtones exceeded \$2.5 billion in 2006 .

\section{RESEARCH METHODOLOGY (COMPARATIVE)}

The study basically concentrates on comparing the customer's perceptions towards cellular phone services provided by the different operators in the state of Tamilnadu. The customers are from both urban and semiurban places of Tamilnadu. In addition, customers were also classified on the basis of the type of services usage.(i.e., post paid or pre paid).The basic parameters used for the purpose of comparing their perceptions are purpose of usage, Accessibility, quality of service, after sale services, economy rate, wire range of services etc. Finally switching behavior of the customer and suggestions were studied at last.

\section{A. Statement of The Problem:}

Communication is the life blood for inter personal relations and for the development of social status. In formal organizations the role of communication is vital for the development of business and to perform it in a planned way. Communication plays a major role not only between the individuals but also between the organizations and countries. Communication helps in exchange of ideas, thoughts and for sharing knowledge required to the development of society. The present study made an attempt to compare the customer's perceptions towards cellular phone services offered in urban and semi urban places of Tamilnadu.

\section{B. Objectives of The Study}

1. To find out the customer perceptions on cellular phone services in Tamilnadu.

2. To assess the factors influencing in the selection of a particular service provider and find out their level of satisfaction among the consumers in TamilNadu.

3. To find out the relationship between the perceptions of the urban and semi urban customers on cellular phone services.

4. To provide suggestions to improve the service quality and satisfaction among the customers in TamilNadu.

\section{HYPOTHESIS TESTED}

\section{A. Primary Hypothesis:}

1. $\mathbf{H}_{\bullet}:$ There is no difference between the perceptions of the customers of rural and urban on value added services. 
2. $\mathbf{H}_{4}$ : There is a difference between the perceptions of the customers of rural and urban on value added services.

3. $H_{0}$ : There is no difference between the perceptions of the customers of rural and urban on mobile service tariffs.

4. $\quad H_{:}$: There is a difference between the perceptions of the customers of rural and urban on mobile service tariffs.

5. $\mathbf{H}_{\circ}$ : There is no difference between the perceptions of the customers of rural and urban on coverage and interruptions.

\section{NATURE AND SCOPE OF THE STUDY}

The present study is basically comparative in nature. The scope of the study can be defined in three dimensions. The primary focus is given to study the perceptions of the customers in urban and semi urban places of Tamilnadu. Customers were classified on the basis of type of service opted for usage as pre- paid users and post-paid users. A comparative study is made between the perception of the above said is made to under stand the perceptions of the different service users. The study is made in selected places of Tamilnadu through convenient sample.

\section{A. Need For The Study}

The basic need in the selection of the present study is to find out the reasons for shifting and to provide some feasible suggestions to control the shifting behavior through improved service quality. The researcher feels that the present study helps to know the perceptions of the customers and the service providers between the two major segments. i.e. urban and semi urban. It gives a proper idea on the customer's expectations. Which in turn helps in designing the various business plans to suit the customers in different segments. This will help the customer in stick on to a particular company. Hence, there is a need to conduct a research at micro level to understand the customer's perceptions towards cellular services. In this study, the researcher is made an attempt in this direction.

\section{B. Sources of Data}

The study uses both primary and secondary data for the purpose of making a comparison between the perceptions of the customer's in urban and semi urban areas of Tamilnadu. Primary data is collected from the customers using different service lines and different types of services. The secondary data is collected from various sources like published, un published print media, web service, and various research reports and special survey reports of the Telecommunications department.

\section{Method of Data Collection}

Data required for the study is collected from both print media and electronic media. The print media includes the research reports, survey reports, special commission reports, articles from the referred journals, columns from news papers, text books and industry reports etc. The electronic media refers to World Wide Web and epublishers. Primary data is collected through a structured questionnaire developed by the researcher.

\section{Tools Used for Data Collection and Structure of the Questionnaire}

The data required for the research is collected by conducting a survey among the sample. For conducting a survey two sets of structured questionnaire is prepared. The first set deals with the pre paid cellular service users and the Second set deals with post paid cellular service users. The questionnaire designed for pre paid service users consists of three parts. PartA deals with profile of the customer on various demographical attributes. Part B deals with the sources of awareness and the reasons for holding a mobile connection. Part $\mathrm{C}$ deals with awareness on the services offered and the perceptions relating to various attributes of service quality. The questionnaire designed for post paid service users consists of three parts. Part A deals with profile of the customer on various demographical attributes. Part $B$ deals with the sources of awareness and the reasons for holding a mobile connection. Part $C$ deals with awareness on the services offered and the perceptions relating to various attributes of service quality.

\section{E. Pilot Study and Reliability Test}

Initially a pilot study is conducted with 50 questionnaires for each category of users for making the opinions and the relevance of some questions were slightly modified for final version of questionnaire. The reliability coefficient of the questionnaire designed for prepaid service users is computed using Corn Bach's Alpha and the value is 0.87 , which shows that the instrument is reliable. Similarly the reliability coefficient value for the questionnaire designed to the post paid service users is 0.89 , which indicates the reliability of the questionnaire.

\section{F. Method of Sample-convenient}

For the purpose of survey, sample is made through a convenient sample method. In order to avoid the extraneous variance, and for statistical concerns, the reasonable sample is drawn. 


\section{G. Sample Profile}

For the purpose of survey, a questionnaire is distributed to the cellular phone users in both urban and semi urban areas of Tamil Nadu. The customers were selected between the age group of below 20 and above 50 years from the both the genders. Other demographical attributes used for the selection of sample are occupation, qualification monthly income, number of working members in a family and number of members in a family.

\section{H. SampleArea}

Sample area is broadly divided into two segments namely urban and semi urban. Urban area is Chennai city and semi urban area includes the selected towns in the state of Tamil Nadu. The semi urban area town includes Coimbatore, Madurai, Trichy, Erode, Tanjore and Tirunalveli.

\section{ANALYSIS \& INTERPRETATION}

\section{A. Demographical Analysis:}

The present study is focused in finding the demographical distribution of cellular phone users and to fond out their perceptions on the services provided by the operators. The analysis is made in the following pages

\section{B. Frequency Analysis:}

From the frequency analysis the following findings were found:

It is observed that majority of the cellular phone users are youth i.e. in the age group of 21-30 years. Where as in case of elders crossed 50 years in urban areas are using mobile phones considerable well when compare to rural. Another significant phenomena observed is the semi urban area , youth i.e. less than 20 years age group are using mobiles at higher rate. It indicates the rural potential for the cellular services.

It is observed from the analysis, that $43 \%$ of the respondents having PG -technical degree in the urban area occupies the top share in the usage of mobile phones, In semi urban areas the scenario is different i.e. $27 \%$ of the sample respondents having UG non-technical degree occupies the major share in the usage of mobile phones.

It is observed from the analysis, that respondents having above 20000 family incomes per month are occupying $65 \%$ of the usage of mobile phones in urban areas. In semi urban majority of the mobile phone users are in the income range of 10000-15000 per month. Income plays a major role in the usage of mobile phones.

\section{Interpretation:}

It is observed from the analysis, that economy is highly significant in both rural and urban areas.

\section{T.TEST}

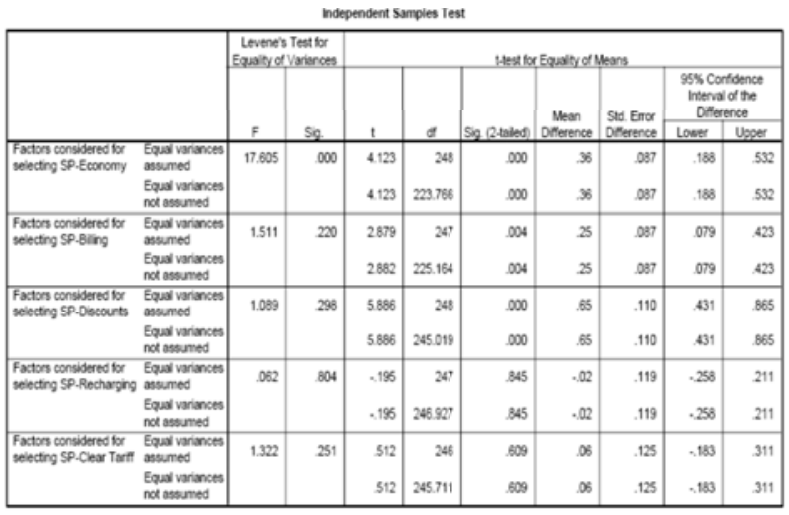

\begin{tabular}{|ll|r|r|r|r|}
\multicolumn{7}{|c|}{ Group Statistics } \\
\hline & District & \multicolumn{1}{c|}{$\mathrm{N}$} & \multicolumn{1}{c|}{ Mean } & Std. Deviation & $\begin{array}{c}\text { Std. Error } \\
\text { Mean }\end{array}$ \\
\hline Factors considered for & Chennai & 125 & 4.71 & .565 & .051 \\
selecting SP-Economy & Semi Urban & 125 & 4.35 & .796 & .071 \\
\hline Factors considered for & Chennai & 124 & 4.40 & .568 & .051 \\
selecting SP-Billing & Semi Urban & 125 & 4.14 & .790 & .071 \\
& & & & & \\
\hline Factors considered for & Chennai & 125 & 4.38 & .821 & .073 \\
selecting SP-Discounts & Semi Urban & 125 & 3.74 & .917 & .082 \\
\hline Factors considered for & Chennai & 124 & 4.09 & .928 & .083 \\
selecting SP-Recharging & Semi Urban & 125 & 4.11 & .952 & .085 \\
\hline Factors considered for & Chennai & 123 & 4.01 & .996 & .090 \\
selecting SP-Clear Tariff & Semi Urban & 125 & 3.94 & .978 & .087 \\
\hline
\end{tabular}

\section{Interpretation}

1. Economy is a significant factor in the selection of a service provider in both rural and urban

2. Billing, Discounts, Recharging and Clear tariff are not significant relation ship in the selection of a service provider.

\section{ONEWAY -ANOVA:}

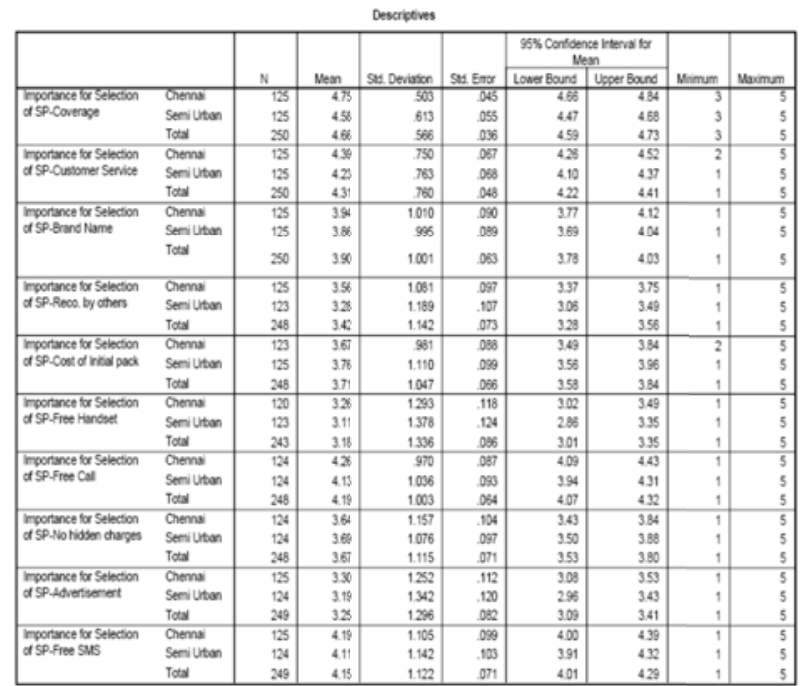




\begin{tabular}{|c|c|c|c|c|c|c|}
\hline \multicolumn{7}{|c|}{ ANOVA } \\
\hline & & $\begin{array}{l}\text { Sum of } \\
\text { Squares }\end{array}$ & $d f$ & Mean Square & $\mathrm{F}$ & Sig. \\
\hline \multirow{3}{*}{$\begin{array}{l}\text { Tmportance for Selection } \\
\text { of SP-Coverage }\end{array}$} & Between Groups & 1.936 & 1 & 1.936 & \multirow[t]{3}{*}{6.16} & \multirow[t]{3}{*}{.014} \\
\hline & Within Groups & 77.840 & 248 & .314 & & \\
\hline & Total & 79.776 & 249 & & & \\
\hline \multirow{3}{*}{$\begin{array}{l}\text { Importance for Selection } \\
\text { of SP-Customer Service }\end{array}$} & Between Groups & 1.600 & 1 & 1.600 & \multirow[t]{3}{*}{2.793} & \multirow[t]{3}{*}{.096} \\
\hline & Within Groups & 142.064 & 248 & .573 & & \\
\hline & Total & 143.664 & 249 & & & \\
\hline \multirow{3}{*}{$\begin{array}{l}\text { Importance for Selection } \\
\text { of SP-Brand Name }\end{array}$} & Between Groups & .400 & 1 & .400 & \multirow[t]{3}{*}{.398} & \multirow[t]{3}{*}{.529} \\
\hline & Within Groups & 249.296 & 248 & 1.005 & & \\
\hline & Total & 249696 & 249 & & & \\
\hline \multirow{3}{*}{$\begin{array}{l}\text { Importance for Selection } \\
\text { of SP-Reco. by others }\end{array}$} & Between Groups & 4.985 & 1 & 4.985 & \multirow[t]{3}{*}{3.864} & \multirow[t]{3}{*}{.050} \\
\hline & Within Groups & 317.402 & 246 & 1.290 & & \\
\hline & Total & 322.387 & 247 & & & \\
\hline \multirow{3}{*}{$\begin{array}{l}\text { Importance for Selection } \\
\text { of SP-Cost of Initial pack }\end{array}$} & Between Groups & .540 & 1 & .540 & \multirow[t]{3}{*}{.498} & \multirow[t]{3}{*}{.484} \\
\hline & Within Groups & 270.133 & 246 & 1.098 & & \\
\hline & Total & 270.673 & 247 & & & \\
\hline \multirow{3}{*}{$\begin{array}{l}\text { Importance for Selection } \\
\text { of SP-Free Handset }\end{array}$} & Between Groups & 1.415 & 1 & 1.415 & \multirow[t]{3}{*}{.792} & \multirow[t]{3}{*}{.374} \\
\hline & Within Groups & 430.618 & 241 & 1.787 & & \\
\hline & Total & 432.033 & 242 & & & \\
\hline \multirow{3}{*}{$\begin{array}{l}\text { Importance for Selection } \\
\text { of SP.Free Call }\end{array}$} & Between Groups & 1.032 & 1 & 1.032 & \multirow[t]{3}{*}{1.025} & \multirow[t]{3}{*}{.312} \\
\hline & Within Groups & 247.677 & 246 & 1.007 & & \\
\hline & Total & 248.710 & 247 & & & \\
\hline \multirow{3}{*}{$\begin{array}{l}\text { Importance for Selection } \\
\text { of SP-No hidden charges }\end{array}$} & Between Groups & .198 & 1 & .198 & \multirow[t]{3}{*}{.158} & \multirow[t]{3}{*}{.691} \\
\hline & Within Groups & 307.024 & 246 & 1.248 & & \\
\hline & Total & 307.222 & 247 & & & \\
\hline \multirow{3}{*}{$\begin{array}{l}\text { Importance for Selection } \\
\text { of SP-Advertisement }\end{array}$} & Between Groups & .759 & 1 & .759 & \multirow[t]{3}{*}{.451} & \multirow[t]{3}{*}{.502} \\
\hline & Within Groups & 415.803 & 247 & 1.683 & & \\
\hline & Total & 416.562 & 248 & & & \\
\hline \multirow{3}{*}{$\begin{array}{l}\text { Importance for Selection } \\
\text { of SP-Free SMS }\end{array}$} & Between Groups & .389 & 1 & 389 & \multirow[t]{3}{*}{.368} & 579 \\
\hline & Within Groups & 311.811 & 247 & 1.262 & & \\
\hline & Total & 312.201 & 248 & & & \\
\hline
\end{tabular}

\section{Interpretation}

1. There is no relationship between the important factors in the selection of service provider and coverage, customer service, brand name, recommendation by others, cost of initial pack, free hand set, free calls, hidden charges, advertisements, free SMS.

\begin{tabular}{|c|c|c|c|c|c|c|}
\hline \multicolumn{7}{|c|}{ ANOVAp } \\
\hline Model & & $\begin{array}{l}\text { Sum of } \\
\text { Squares }\end{array}$ & df & Mean Square & $\mathrm{F}$ & Sig. \\
\hline 1 & Regression & 11.024 & 5 & 2.205 & 10.487 & $.000^{9}$ \\
\hline & Residual & 50.460 & 240 & .210 & & \\
\hline & Total & 61.484 & 245 & & & \\
\hline
\end{tabular}

a. Predictors: (Constant), Factors considered for selecting SP-Clear Tarift, Factors considered for selecting SP-Discounts, Factors considered for selecting SP-Recharging, Factors considered for selecting SP-Economy, Factors considered for selecting SP-Billing

b. Dependent Variable: District

\section{SUGGESTIONS}

Based on the sample data interpretation, the researcher presents the following suggestions to improve the service quality and customer reach of the mobile phone facilities in both urban and rural areas.

1. Coverage and connectivity problems can be removed through hi-tech facilities both in urban and rural areas, which improve the customer satisfaction and brand loyalty to a greater extent.
2. Service charges can be reduced in rural areas through special schemes, which can attract more customers in rural areas.

3. Modus operation of customer care centers can be changed to direct access than dial up channel.

4. STD rates can be reduced with unification of service area and coverage.

5. Clarity of voice and connectivity problems is to be taken care at all points of time.

6. Grace period can be given to the regular customers both on pre paid and post paid services.

7. Tariff rates should be designed in an attractive way to satisfy the customer from time to time.

8. Control of tapping and other fraudulent activities needs to be improved for better service control.

9. Low cost technology with add on facilities needs to be provided.

10. Service facilities are to be customer friendly and reliable in nature. Youth attractive schemes can be launched separately.

\section{CONCLUSION}

Mobile phone services are becomes the order of the day. Technology plays a major role in the success of the service provider. Coverage, economy and flexibility are the primary drivers of the market. The services provided by the operators may not vary to a greater extent. Customer orientation is the need of an hour. The difference between the perceptions of the rural and urban is negligible. It indicates the need for uniform services in the years to come. Let us hope for the same to be happen at the earliest.

\section{REFERENCES}

[1] Research Methodology by Kothari.

[2] Riel, A.C., Liljander, V., and Jurriens, P. ( 2001). Exploring customer evaluations of e-services: a portal site", International Journal of Service Industry Management, 12 (4), 359-377

[3] Rigby, D., Reichheld, E., Schefter, P. (2002). Avoiding the four perils of CRM, Harvard Business Review, 80 (2), 101-109 
[4] Sigala, M. (2003b). The Information \& Communication Technologies productivity impact on the UK hotel sector. International Journal of Operations and Production Management, 23 (10), 1224-1245.

[5] Tallon, P., Kraemer, K. and Gurbaxani, V. (2000). Executives' perceptions of the business value of

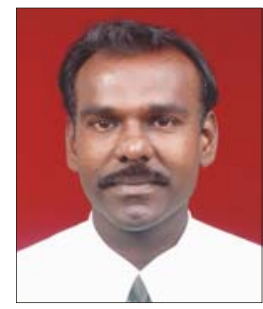

Mr. Muthumani - Senior Lecturer, Department of Management Studies Sathyabama University. He has ten years of academic experience. He has organized several workshops and has published 4 papers in the journals and has presented 11 papers in national and in international conferences. approach, Journal of MIS, 16 (4), 145-173 